\title{
Protective Role of Interleukin-17 in Murine NKT Cell-Driven Acute Experimental Hepatitis
}

\author{
Zenebech Wondimu, Tania Santodomingo-Garzon, \\ Tai Le, and Mark G. Swain \\ From the Immunology Research Group, University of Calgary, \\ Calgary, Alberta, Canada
}

NKT cells are highly enriched within the liver. On activation NKT cells rapidly release large quantities of different cytokines which subsequently activate, recruit, or modulate cells important for the development of hepatic inflammation. Recently, it has been demonstrated that NKT cells can also produce interleukin-17 (IL-17), a proinflammatory cytokine that is also known to have diverse immunoregulatory effects. The role played by IL-17 in hepatic inflammation is unclear. Here we show that during $\alpha$-galactosylceramide ( $\alpha$ GalCer)-induced hepatitis in mice, a model of hepatitis driven by specific activation of the innate immune system via NKT cells within the liver, $\mathrm{NK} 1.1^{+}$and $\mathrm{CD}^{+}{ }^{+}$iNKT cells rapidly produce $\mathrm{IL}-17$ and are the main $\mathrm{IL}-17$-producing cells within the liver. Administration of IL-17 neutralizing monoclonal antibodies before $\alpha$ GalCer injection significantly exacerbated hepatitis, in association with a significant increase in hepatic neutrophil and proinflammatory monocyte (ie, producing IL-12, tumor necrosis factor- $\alpha$ ) recruitment, and increased hepatic mRNA and protein expression for the relevant neutrophil and monocyte chemokines CXCL5/LIX and CCL2/MCP-1, respectively. In contrast, administration of exogenous recombinant murine IL-17 before $\alpha$-GalCer injection ameliorated hepatitis and inhibited the recruitment of inflammatory monocytes into the liver. Our results demonstrate that hepatic iNKT cells specifically activated with $\alpha$-GalCer rapidly produce $\mathrm{IL}-17$, and $\mathrm{IL}-17$ produced after $\alpha$-GalCer administration inhibits the development of hepatitis. (AmJ Pathol 2010, 177:2334-2346; DOI: 10.2353/ajpath.2010.100028)

The cytokine interleukin-17A (IL-17) has been increasingly identified as an important regulator of the inflammatory response. ${ }^{1-3}$ Initially, a new subset of $\mathrm{CD} 4^{+} \mathrm{T}$ cells were considered to be the source of $\mathrm{IL}-17$ and were classified as Th17 cells. ${ }^{2,3} \mathrm{IL}-17$ secreted from Th17 cells was implicated as a proinflammatory mediator in a number of experimental models of inflammation, especially those associated with autoimmunity and an adaptive immune response. ${ }^{4-6}$ However, more recently IL-17 has also been shown to be able to suppress inflammatory responses, mainly in experimental models which are characterized by a more pronounced innate immune response. Specifically, IL-17 has been shown to suppress inflammation in experimental murine models of asthma, ${ }^{7}$ gastritis, ${ }^{8}$ colitis, ${ }^{9,10}$ and atherosclerosis. ${ }^{11}$ However, the role of IL-17 in regulating hepatic inflammation remains unclear. In patients with viral hepatitis, alcoholic liver disease, and autoimmune liver diseases, numbers of IL17-producing hepatic $T$ cells are increased. ${ }^{12}$ In murine models of liver inflammation the role of IL-17 in regulating the inflammatory response remains controversial. In murine T-cell-mediated hepatitis induced by concanavalin A administration, IL-17 has been shown to be both proinflammatory, as well as without a direct inflammation modulating role. ${ }^{13,14}$

NKT cells are an important component of the innate immune response and are highly enriched within the liver. ${ }^{15}$ NKT cells are activated by glycolipid antigens presented in association with the major histocompatibility complex class I-like molecule CD1d expressed on the surface of antigen presenting cells. ${ }^{16}$ Activation of NKT cells in this fashion results in the rapid production and release of large amounts of both Th1; eg, interferon (IFN) $\gamma$, tumor necrosis factor (TNF) $\alpha$, and Th2 (eg, IL-4) cytokines. ${ }^{16}$ NKT cells have been implicated in human liver disease and are of critical importance in the initiation and development of hepatitis in numerous murine mod-

Supported by operating grants to M.G.S. from the Canadian Institutes of Health Research. M.G.S. is an Alberta Heritage Foundation for Medical Research Senior Scholar. Z.W. was funded through Canadian Association for the Study of the Liver/Canadian Institutes of Health Research Fellowship and the Canadian Institute for Health Research funded University of Calgary Immunology Training Program.

Accepted for publication June 29, 2010.

Address reprint requests to Professor Mark G. Swain, M.D., M.Sc., F.R.C.P.C., Immunology Research Group, Health Sciences Center, University of Calgary, 3330 Hospital Dr., NW, Calgary, Alberta, Canada, T2N 4N1. E-mail: swain@ucalgary.ca. 
els. ${ }^{15,17,18}$ More recently, NKT cells have also been shown to be capable of rapidly producing IL-17 after activation. ${ }^{19-21}$ To date $\mathrm{IL}-17$ has been reported to be produced mainly by type II (ie, non-invariant) and NK1.1 negative NKT cells ${ }^{19,22,23}$; however, within the murine liver most NKT cells express CD4 and NK1.1 and are classified as invariant (iNKT) or type I NKT cells. ${ }^{15,16}$

$\alpha$-Galactosylceramide ( $\alpha$ GalCer) is a glycolipid, originally isolated from a marine sponge, which specifically activates iNKT cells in both humans and mice after being presented by antigen presenting cells in the context of CD1d. ${ }^{16}$ iNKT cells activated in this fashion can in turn transactivate numerous other cell types within the liver, including other components of the innate immune response such as macrophages and NK cells. ${ }^{24,25}$ This property of $\alpha \mathrm{GalCer}$ has generated interest in developing this compound as an immune stimulating agent for the treatment of human disease, including liver cancers. ${ }^{24}$ However, $\alpha$ GalCer treatment also induces hepatitis in mice and therefore has been used as an experimental model to study hepatic immune and inflammatory responses which result from the specific activation of iNKT cells and the subsequent downstream stimulation of the hepatic innate immune system. ${ }^{26,27}$

Therefore, we undertook this series of experiments to determine first whether hepatic NK1.1 positive iNKT cells could also produce IL-17 after specific activation. In addition, given that the adaptive Th17 response develops more slowly, we wanted to determine the role of $\mathrm{IL}-17$, released as part of the early iNKT cell-driven innate hepatic immune response, in the regulation of hepatitis induced by the administration of $\alpha \mathrm{GalCer}$.

\section{Materials and Methods}

\section{Mice}

Male C57BL/6 mice were used (8-10 weeks old; The Jackson Laboratories, Bar Harbor, ME). All procedures were approved by the Animal Care Committee of the University of Calgary (protocol M07028) and were performed in accordance with the guidelines of the Canadian Council on Animal Care.

\section{Antibodies and Other Reagents}

The following reagents and antibodies were obtained from indicated sources: $\alpha$-galactosylceramide ( $\alpha$ GalCer, Alexis Biochemicals, San Diego, CA), collagenase type 2 (Cedarlane Laboratories, Burlington, ON, Canada), DNase I (Roche Diagnostics, Laval, Quebec, Canada), PBS57 (analog of $\alpha$-GalCer) loaded CD1d tetramer conjugated to phycoerythrin (PE; kindly provided by National Institute of Allergy and Infectious Diseases, National Institutes of Health Tetramer Core Facility, Atlanta, GA). Purified or fluorescent conjugated monoclonal antibodies (mAbs) were purchased from the following suppliers: PerCp anti-CD4 (RM4-5), Percp-Cy5.5 anti-NK1.1 (PK136), fluorescein isothiocyanate (FITC) anti-TNF $\alpha$ (MP6-XT22), FITC or PE anti-CD11b (M1/70), PE anti-
IL-12 (P40/P70, C15.6), PE anti IL-17A (TC11-18H10), anti-CD16/CD32 (2.4G2; BD Biosciences, Mississauga, ON, Canada); PE-Cy5 anti-F4/80 (BM8), FITC anti-Ly-6G (Gr1, RB6-8C5), FITC anti-IL-17 (eBio1757; eBioscience Inc, San Diego, CA); anti-Ly-6C (ER-MP20) and goat anti-rat IgG-FITC (Santa Cruz Biotechnology Inc., Santa Cruz, CA); PE-anti-IFN $\gamma$ (XMG1.2) (BD Biosciences); PEanti-IL-10 (JES5-16E3; eBioscience); PE anti-IL-4 (BVD41D11; BD Biosciences); primary anti-CCR2 (CKR-2B; Santa Cruz); and bovine anti-goat IgG PE secondary antibody (sc-3747; Santa Cruz); FITC annexin V (catalog no. 556419, BD Biosciences); anti-CCL2 (LS-C71953; LifeSpan Biosciences, Seattle, WA); and anti-CXCL5 (500-P146; PreproTech, Inc, Rocky Hill, NJ).

\section{Hepatitis Induction and Sample Preparation}

To induce hepatitis, a single intravenous injection of $\alpha$ GalCer (2 $\mu \mathrm{g}$ in $100 \mu \mathrm{l}$ vehicle; $2 \%$ DMSO and 0.04\% Tween 20 in sterile PBS was administered per mouse. ${ }^{26,27}$ Controls received $100 \mu$ l of vehicle. For IL-17 neutralization, a single dose of either $75 \mu \mathrm{g}$ per mouse anti-mouse IL-17 mAb, or ratlgG2a isotype control, was injected intravenously 1 hour before $\alpha$ GalCer administration [anti-mouse IL-17 neutralizing mAb (MAB421) and rat IgG isotype control (MAB006); R\&D Systems, Minneapolis, MN]. 10,28 To confirm important findings obtained with the R\&D Systems neutralizing anti-IL-17 antibody (MAB421), we repeated some of the experiments with a second commercially available IL-17 neutralizing monoclonal antibody targeted to a different IL-17 epitope than the R\&D Systems IL-17 neutralizing antibody (LEAF purified anti-mouse IL-17 neutralizing mAb (TC11-18H10.1) and LEAF purified rat IgG1 isotype control (RTK2071); BioLegend, San Diego, CA). ${ }^{29}$ In additional experiments the effects of exogenous recombinant murine (rm) IL-17 administration on $\alpha$ GalCer-induced hepatitis severity was determined [rmlL-17 (421-ML/CF); R\&D Systems, Minneapolis, MN]. ${ }^{11}$ For these experiments $\mathrm{rmlL}-17,1 \mu \mathrm{g} /$ mouse, or PBS vehicle was injected intraperitoneally 30 minutes before and 1 hour after $\alpha$ GalCer administration. ${ }^{8}$

Initially, at 2, 8, 16, 24, and 48 hours after $\alpha$ GalCer or vehicle treatment mice were sacrificed and serum collected and livers perfused through the portal vein with sterile ice-cold PBS. To assess the degree of hepatic injury, blood was collected and alanine aminotransferase (ALT) levels measured (commercial kit; Biotron Diagnostics, Hemet, CA), and liver tissue samples collected in $10 \%$ buffered formalin for histological examination after $\mathrm{H} \& \mathrm{E}$ staining. $\alpha$ GalCer-induced hepatic injury is associated with a predominant innate immune response characterized by the early activation of iNKT cells and the subsequent accumulation of neutrophils and monocytes within the liver. ${ }^{30}$ Therefore, we determined recruited neutrophil and monocyte positioning within the liver by immunohistochemistry at 16 hours after $\alpha$ GalCer treatment. Neutrophil recruitment to the liver was assessed by nonspecific esterase (Leder) staining of formalin fixed paraffin embedded liver tissue sections as previously described. ${ }^{31}$ Monocyte recruitment to the liver was as- 
sessed by immunohistochemical staining of Ly- $6 \mathrm{C}$ antigen (a cell surface marker highly expressed on infiltrating monocytes but not on resident tissue macrophages including Kupffer cells) $)^{32}$ in formalin-fixed paraffin-embedded liver sections. ${ }^{33}$ Endogenous peroxidase and endogenous biotin binding were blocked using $3 \% \mathrm{H}_{2} \mathrm{O}_{2}$ and an avidin/biotin blocking kit (Vector Laboratories, Burlingame, $C A$ ), respectively, and then stained with anti Ly- $6 \mathrm{C}$ mAb. The bound antibody was detected by the peroxidase-labeled avidin-biotin complex method and diaminobenzidine (Fast DAB, Sigma) was used as a substrate for color development. Sections were then counterstained with Gills II hematoxylin.

In addition, at specified time points after $\alpha$ GalCer or vehicle administration liver tissue was collected in Trizol reagent (Invitrogen, Burlington, ON, Canada) for RNA isolation or treated with digestion buffer $(0.05 \%$ collagenase 2 and $0.02 \%$ DNase I in Hanks' balanced salt solution with $\mathrm{Ca}^{2+}$ and $\mathrm{Mg}^{2+}$ ions) for cell isolation. Hepatic mononuclear cells were isolated by discontinuous Percoll gradient (GE HealthCare Biosciences, Baue D'urfe, Quebec, Canada) as previously described. ${ }^{18,25}$ Cell viability was assessed by Trypan Blue dye exclusion. Single cell suspensions $\left(0.5-1.0 \times 10^{6}\right.$ cells per sample) were prepared in binding buffer ( $1 \%$ fetal bovine serum in PBS) for flow cytometric staining.

\section{Blood and Hepatic IL-17 Level Measurements}

Plasma and livers were collected 2, 8, 16, and 24 hours after $\alpha \mathrm{GalCer}$ or vehicle treatment and IL-17 levels were measured using a commercial enzyme-linked immunosorbent assay (BioLegend, San Diego, CA). For hepatic IL-17 measurements livers were perfused (as above) and whole livers were homogenized in $2 \mathrm{ml}$ of buffer containing protease inhibitors, centrifuged, and filtered as described previously in detail. ${ }^{18,25}$

\section{Flow Cytometry Analyses}

Immunophenotyping and intracellular cytokine detection were done by direct immunofluorescence using multicolor flow cytometry staining of isolated hepatic mononuclear cells, or total leukocytes, as previously described. ${ }^{18}$ $\mathrm{FC} \gamma \mathrm{III} / \mathrm{II}$ receptors were blocked by incubating isolated cells with anti-CD16/CD32. Hepatic NKT cells were identified by simultaneous staining with anti-CD3 or -CD4PerCp or -NK1.1-FITC and CD1d-PBS57/PE; hepatic monocytes and neutrophils were identified by simultaneous staining with anti-F4/80-PE-Cy5 and -Ly-6G(Gr1)FITC. In additional experiments monocytes were alternatively identified by staining with rat anti-mouse Ly-6C $\mathrm{mAb}$ and detected with a secondary goat anti-rat IgGFITC. Tissue macrophages, including Kupffer cells, are Ly-6C negative. ${ }^{32}$ For intracellular cytokine detection, cells were stained with mAbs to respective cell surface antigens and were then fixed and permeabilized with Cytofix/Cytoperm buffer (BD Biosciences) and stained with anti-IL-17-FITC, -IL-17-PE, or -TNF $\alpha$-FITC, or -IL12-PE, or -IFN $\gamma$-PE, or -IL-4-PE, or -IL-10-PE, or -annexin
V-FITC. Cell surface CCR2 expression was determined using an unconjugated anti-CCR2 and PE-labeled secondary antibodies. Stained cells were acquired and analyzed using a FACScan flow cytometer (Becton Dickinson, Mountain View, CA) using CellQuest Alias software. iNKT cells producing IL-17 were identified by gating on NK1.1 or CD4 and CD1d-PBS57 double positive cells that were positive for IL-17. Similarly, monocytes producing IL-12, TNF $\alpha$, or IL-10 were identified by gating on cells that were double positive for $F 4 / 80$ and IL-12, IL-10, or TNF $\alpha$.

\section{Quantitative RT-PCR}

Infiltration of inflammatory cells into the tissues is regulated by chemokines. ${ }^{34}$ The chemokines CCL2/MCP-1 or CXCL1/KC, CXCL2/MIP-2 and CXCL5/LIX have been directly implicated in the recruitment of monocytes and neutrophils, respectively, into tissues during an inflammatory response. ${ }^{35,36}$ Therefore, we determined the hepatic expression of these four chemokines using real-time PCR in mice pretreated with IgG or anti-IL-17 neutralizing antibody and sacrificed 2 hours after $\alpha$ GalCer treatment. Total RNA was extracted from $100 \mathrm{mg}$ of liver tissue frozen in Trizol reagent (Invitrogen Canada Inc., Burlington, ON, Canada) from IgG control and anti-IL-17-treated mice according to standard protocols. ${ }^{37}$ The hepatic expressions of CCL2/MCP-1, CXCL1/KC, CXCL2/MIP-2 and CXCL5/LIX mRNAs (primers from SABiosciences, Frederick, MD) were analyzed by real-time quantitative PCR using $\mathrm{RT}^{2}$ SYBR Green/ROX qPCR Master Mix (SABiosciences). Data were analyzed with ABI Prism 7000 SDS software (Applied Biosystems) using a relative quantification method according to the manufacturer's protocol. Expression levels of the target genes were normalized to endogenous GAPDH expression. Data are presented as fold-increase in hepatic chemokine mRNA expression relative to levels determined for vehicle-treated mice.

To complement our mRNA findings, hepatic CXCL5 and CCL2 protein expression was determined by immunohistochemistry, using previously described methods, ${ }^{38,39}$ in formalin fixed paraffin-embedded liver sections obtained from anti-IL-17-pretreated mice 16 hours after $\alpha$ GalCer administration ( $n=3$ mice) as described above for Ly-6C staining (CCL2 primary antibody 100 $\mu \mathrm{g} / \mathrm{ml}$, used in 1:200 dilution; CXCL5 primary antibody $100 \mu \mathrm{g} / \mathrm{ml}$, used in 1:25 dilution).

\section{Bone Marrow-Derived Macrophage Cultures}

Murine bone marrow-derived macrophages were obtained from femurs and tibias from C57BL/6 mice using standard techniques. ${ }^{40}$ The cells were cultured in Dulbecco's modified Eagle's medium (high glucose with L-glu and Na pyruvate; GIBCO, Carlsbad, CA) and activated overnight with IFN $\gamma(100 \mathrm{U} / \mathrm{ml}$; PreproTech, Inc.) plus endotoxin (lipopolysaccharide; $0.1 \mu \mathrm{g} / \mathrm{ml}$; E. coli 0111:B4, Sigma-Aldrich, St. Louis, MO) either in the presence or absence of rmlL-17 (100 pg/ml; R\&D Systems). ${ }^{41}$ 


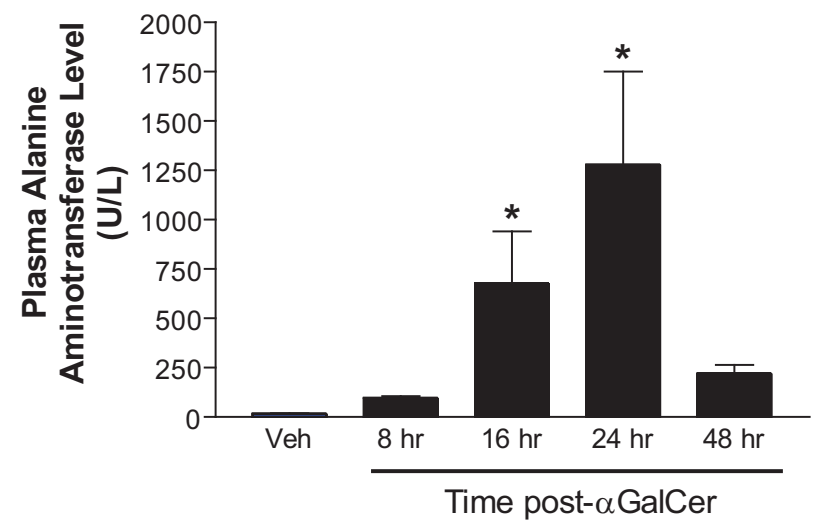

Figure 1. Plasma ALT levels (U/L) in vehicle-treated or $\alpha$ GalCer-treated mice at $8,16,24$, and 48 hours after treatment. Bars represent the mean $\pm \mathrm{SD}$ of data from seven vehicle-treated mice and five $\alpha$ GalCer-treated mice per time point. ${ }^{*} P \leq 0.01$ versus vehicle-treated group

Cells were harvested and IL-12-expressing macrophages determined by flow cytometry.

\section{Statistics}

Results are expressed as means \pm SD. Statistical significance was assessed using an unpaired Student's t-test for comparisons between two groups or by an analysis of variance followed by the Student-Newman-Keuls posthoc test for comparisons between more than two groups, using GraphPad Instat 3 software (GraphPad Software
Inc., La Jolla, CA). Differences between means were considered significant when $P \leq 0.05$.

\section{Results \\ $\alpha \mathrm{GalCer}$ Administration Induces Hepatitis and the Rapid Production of IL-17}

Administration of $\alpha \mathrm{GalCer}$ to mice has been shown to induce hepatitis $24,26,27$ as reflected by a significant increase in plasma ALT levels within 12 to 24 hours, reaching maximal levels between 16 and 24 hours after injection. ${ }^{27}$ We confirm that $\alpha$-GalCer $(2 \mu \mathrm{g} /$ mouse iv) induces a significant acute biochemical hepatitis reflected by elevations in plasma ALT levels which were maximal at 16 to 24 hours after $\alpha \mathrm{GalCer}$ treatment, and which were significantly lower by 48 hours after treatment (Figure 1). In addition, hepatic damage was confirmed histologically in H\&E-stained liver sections (Figure 2). Within 2 hours after $\alpha$ GalCer administration obvious endothelial cell damage and endothelitis was noted in the portal and central veins (Figure 2A). By 8 hours after $\alpha$ GalCer administration inflammatory cell infiltration within the liver was readily identified and, although somewhat patchy, was mainly confined to the portal areas (zone 1) and to a lesser extent around central veins (zone 3) (Figure 2B); however, by 16 hours after $\alpha$ GalCer treatment areas of spotty necrosis were also noticeable within the hepatic lobules (zone 2; Figure 2C), and were slightly more pro-
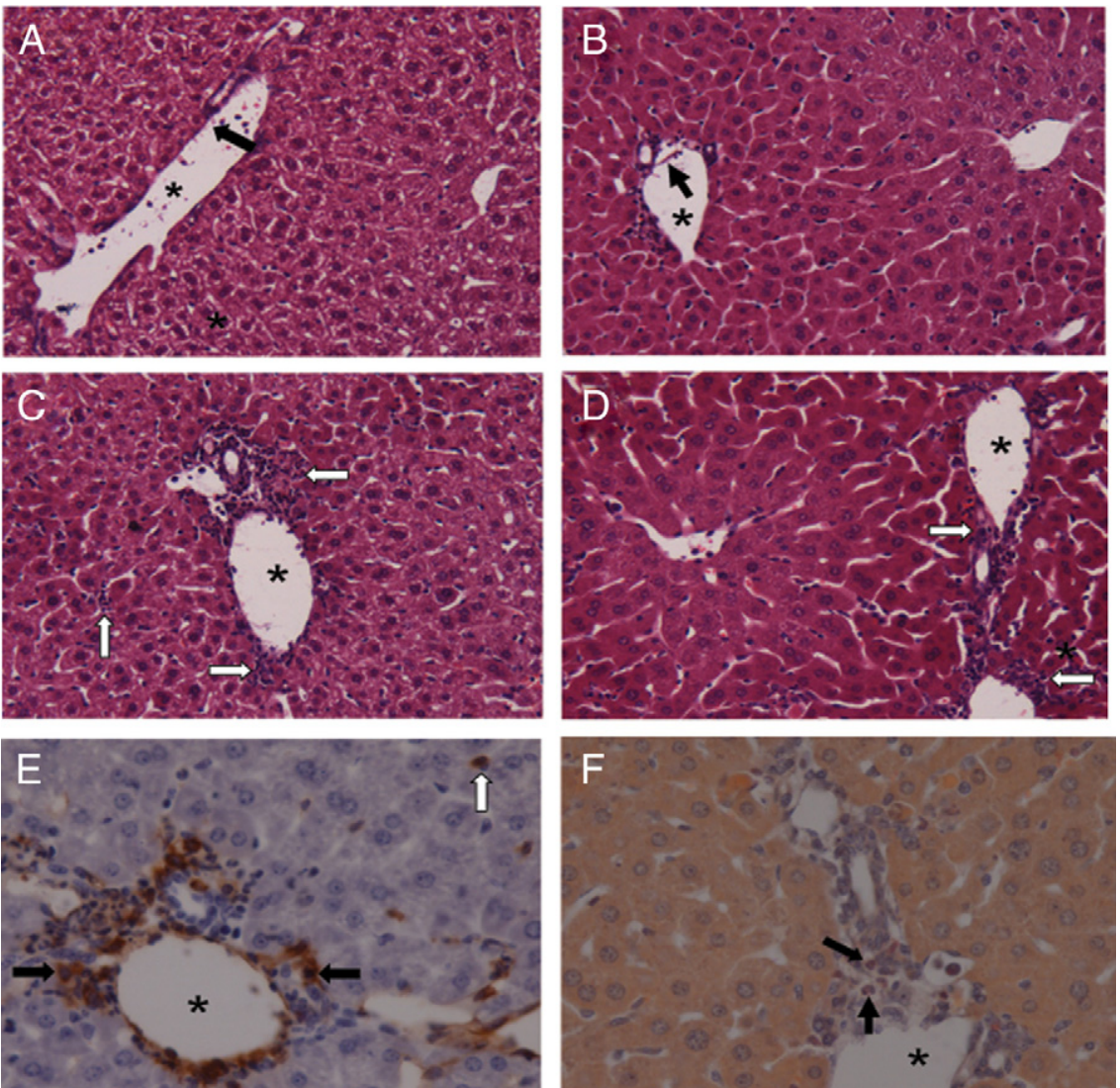

Figure 2. Representative H\&E stained liver sections from $\alpha$ GalCer-treated mice at 2 hours (A), 8 hours (B), 16 hours $(\mathbf{C})$, and 24 hours (D) after $\alpha$ GalCer administration (magnification, $\times 20$ ) The asterisks indicate the portal vein. Black arrows indicate endothelitis, and leukocytes adhering to the endothelium are readily identified within the lumens of the portal and central veins White arrows indicate areas of piecemeal and lobular necrosis. Note most of the inflammatory cell infiltration is located within or adjacent to zone 1 of the liver (ie, portal area) and is comprised mainly of monocytes and neutrophils as demonstrated in $\mathbf{E}$ and $\mathbf{F}$. E: Ly- $6 \mathrm{C}$ positive staining monocytes are shown as brown cells identified by the black arrows. The white arrow indicates a monocyte within the sinusoid (magnification, $\times 40)$. F: Positive esterase stained neutrophils are pink with multilobed nuclei and are indicated by the black arrows (magnification, $\times 40$ ). 


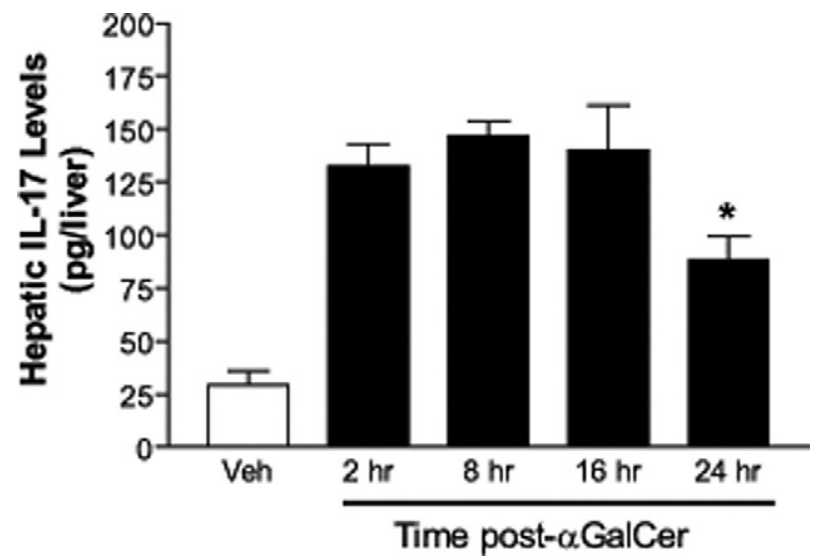

Figure 3. Hepatic IL-17 levels (pg/liver) in vehicle-treated or $\alpha$ GalCer mice at $2,8,16$, and 24 hours after treatment. Bars represent the mean $\pm \mathrm{SD}$ of data from four or five mice/group. Hepatic IL-17 levels are significantly elevated at 2,8 , and 16 hours $(P \leq 0.001)$ and at 24 hours $(P \leq 0.01)$ post- $\alpha$ GalCer compared to levels in vehicle-treated mice. Hepatic IL-17 levels are significantly lower in $\alpha$ GalCer-treated mice at 24 hours $\left({ }^{*} P \leq 0.05\right.$ ) compared to levels in $\alpha$ GalCer-treated mice at 2, 8, and 16 hours after $\alpha$ GalCer treatment.

nounced at 24 hours post- $\alpha$ GalCer (Figure 2D). Moreover, within the hepatic vasculature (ie, portal and central veins), at all time points after $\alpha$ GalCer treatment, inflammatory cells were readily observed apparently adhering to the endothelium within the vessel lumen (Figure 2). At 16 hours after $\alpha \mathrm{GalCer}$ treatment the composition of the hepatic inflammatory cellular infiltrate was further assessed by specifically staining for the presence of neutrophils (esterase staining) and monocytes (Ly-6C staining), as outlined above. Indeed, the hepatic inflammatory cellular infiltrate at 16 hours after $\alpha$ GalCer administration was enriched in both neutrophils and monocytes (Figure 2, $\mathrm{E}$ and $\mathrm{F}$ ). In addition, monocytes were also readily identifiable within the hepatic sinusoids (Figure 2E).

$\alpha$ GalCer treatment resulted in a rapid and robust release of IL-17 into blood (plasma IL-17 levels 2 hours post- $\alpha$ GalCer $106.2 \pm 51.3 \mathrm{pg} / \mathrm{ml} ; n=5$ mice, but were undetectable in vehicle-treated mice or in mice at 8 , 16 , or 24 hours after $\alpha$ GalCer treatment; $n=4-5$ mice/group). In addition, hepatic IL-17 levels rose rapidly and strikingly to maximal levels by 2 hours after $\alpha$ GalCer treatment, and remained at similar levels until starting to decrease at 24 hours after $\alpha$ GalCer treatment (Figure 3).

Therefore, given the time course of hepatitis induction and hepatic IL-17 production after $\alpha$ GalCer treatment, in our further studies to characterize the hepatic cell types producing $\mathrm{IL}-17$, and to determine the role played by $\mathrm{IL}-17$ in the hepatic injury induced by $\alpha$ GalCer treatment, we studied mice at the 2 hour and/or 16 hour time points after $\alpha$ GalCer or vehicle treatment.

\section{Hepatic NK1.1 $1^{+}$and CD4 ${ }^{+}$iNKT Cells Rapidly Produce IL-17 After $\alpha$ GalCer Treatment}

Recently, NK1.1 $1^{\text {neg }}$ iNKT cells have been shown to produce IL-17 when activated non-physiologically with antiCD3 plus anti-CD28 antibodies in vitro. ${ }^{19,22,23,42}$ How-
A
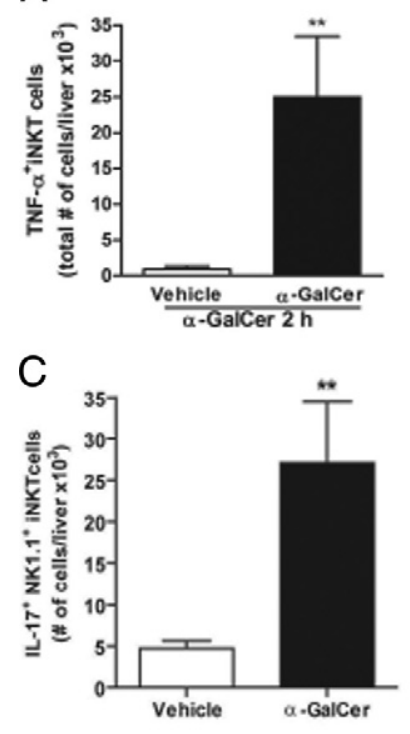

B
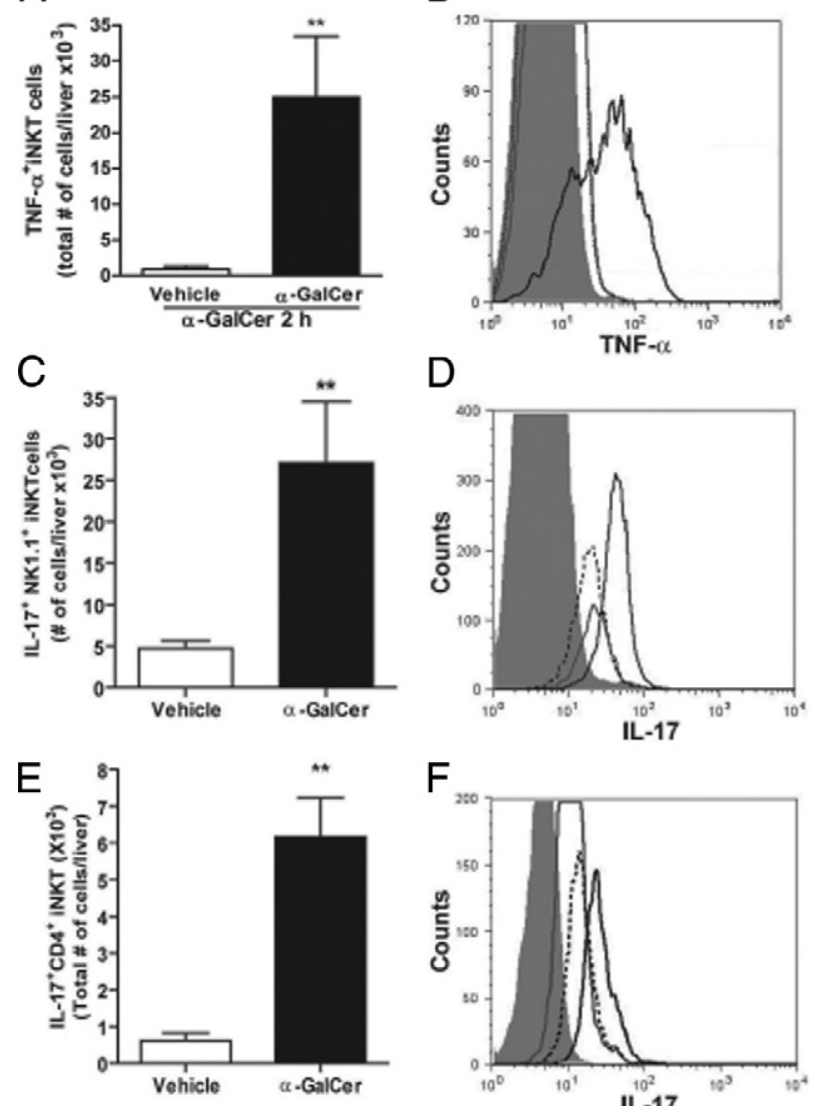

F

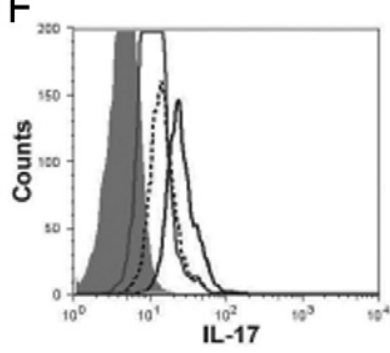

Figure 4. In vivo activated $\mathrm{NK} 1.1^{+}$and $\mathrm{CD} 4{ }^{+}$iNKT cells rapidly produce IL-17 and TNF $\alpha$. Hepatic mononuclear cells were isolated 2 hours after $\alpha$ GalCer or vehicle treatment and were analyzed by flow cytometry using PBS57 loaded CD1d tetramers, anti-CD4, NK1.1, IL-17, and TNF $\alpha$ mAbs. A: Total number of $\mathrm{TNF}^{+} \mathrm{CD} 4^{+} \mathrm{CD} 1 \mathrm{~d}$ tetramer $^{+}$(iNKT) cells per liver. B: Representative histogram plot for $\mathrm{TNF}^{+} \mathrm{CD}^{+}{ }^{+}$iNKT cells. C: Total number of IL- $17^{+}$NK $1.1^{+}$CD1d tetramer ${ }^{+}$iNKT cells per liver. D: Representative histogram plot for IL- $17^{+} \mathrm{NK} 1.1^{+}$iNKT cells. E: Total number of $\mathrm{IL}-17^{+} \mathrm{CD} 4^{+} \mathrm{CD} 1 \mathrm{~d}$ tetramer $^{+}$iNKT cells per liver. F: Representative histogram plot for IL$17^{+} \mathrm{CD}^{+}{ }^{+}$iNKT cells. In each histogram plot the shaded histogram represents the isotype control, the gray line the vehicle-treated group, and the black line the $\alpha$ GalCer-treated group. In each of the representative histograms the dotted line indicates basal levels of NKT cell cytokine expression in nontreated controls. Bars represent the mean $\pm \mathrm{SD}$ of data from five mice/group; ${ }_{* *} P<0.005$. Experiments were repeated more than three times with similar results.

ever, the majority of hepatic iNKT cells in the C57BL/6 mouse (accounting for more than $80 \%$ of NKT cells) are $\mathrm{NK} 1.1^{+} .{ }^{15}$ Therefore, we felt that this NK1.1 ${ }^{+}$subpopulation of NKT cells may also produce $\mathrm{IL}-17$ on more physiological activation via $\alpha$-GalCer stimulation in vivo. It has been previously shown that $\alpha \mathrm{GalCer}$ administration activates iNKT cells which rapidly produce TNF $\alpha$, an important mediator of liver injury in this model. ${ }^{27}$ Indeed, we confirm by flow cytometry that iNKT cells rapidly produce TNF $\alpha$ within 2 hours after $\alpha$ GalCer injection (Figure $4, A$ and $B$ ).

We next determined whether hepatic iNKT cells (specifically, $\mathrm{NK} 1.1^{+}$and $\mathrm{CD} 4^{+}$iNKT cells) could also produce IL-17 after $\alpha$-GalCer treatment. Using flow cytometry, hepatic IL-17-producing NK1.1 ${ }^{+}$iNKT and CD4 ${ }^{+}$ iNKT cells were readily identified at 2 hours after $\alpha$-GalCer administration (Figure 4, C-F). At 16 hours after $\alpha \mathrm{GalCer}$ 
A

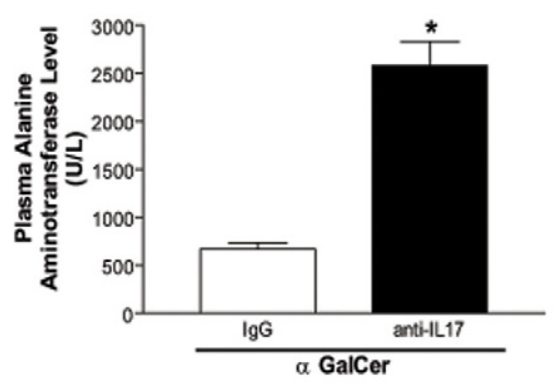

C

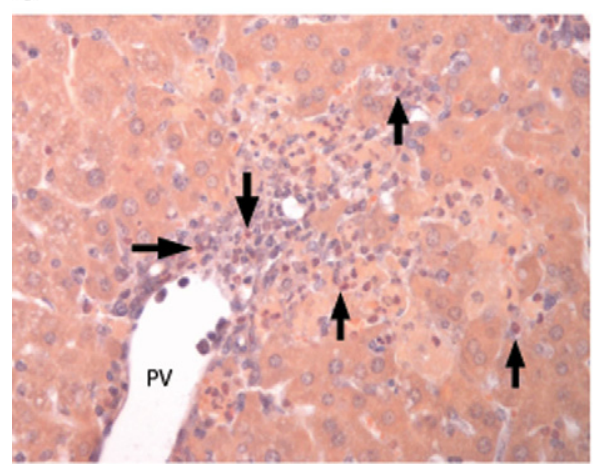

B
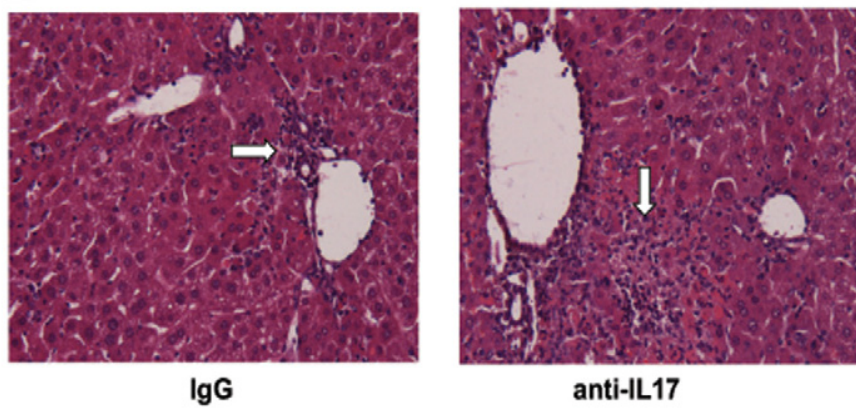

anti-IL17

D

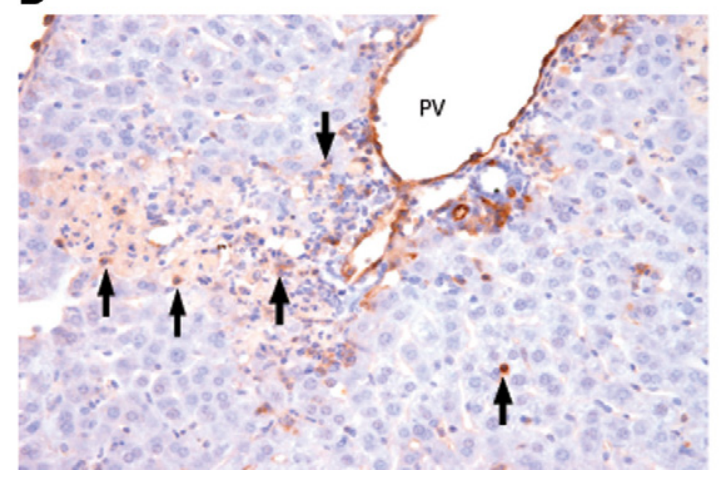

Figure 5. IL-17 neutralization exacerbates $\alpha$-GalCer-induced hepatitis. A: $\alpha$ GalCer-induced increases in plasma ALT levels are significantly enhanced in mice pretreated with an anti-IL-17 neutralizing antibody, compared to IgG istotype pretreated mice, at 16 hours after $\alpha$ GalCer administration. Bars represent the mean \pm $\mathrm{SD}$ of data from $n=5 \mathrm{IgG}$ and 7 anti-IL-17-treated mice. ${ }^{*} P \leq 0.015$ versus IgG-treated group. Experiments for plasma ALT measurement were repeated three times with similar results. B: Representative H\&E-stained liver sections from IgG and anti-IL-17-pretreated mice at 16 hours after $\alpha$ GalCer administration indicate enhanced piecemeal and lobular hepatitis (white arrows) in anti-IL-17-treated mice. Similar findings were observed in liver sections obtained from three mice/group. The lobular inflammatory infiltrates were composed of neutrophils and monocytes as evident in $\mathbf{C}$ and $\mathbf{D}$. C: Esterase-stained neutrophils are pink and indicated by black arrows. D: Ly-6C positive stained monocytes are dark brown and indicated by black arrows. Similar findings were observed in liver sections obtained from three mice/group. PV, portal vein.

treatment, a significant increase in hepatic iNKT cells producing IL-17 was also noted $\left(\% \mathrm{CD} 3^{+} \mathrm{NK} 1.1^{+} \mathrm{IL}-17^{+}\right.$ NKT cells at 16 hours after vehicle or $\alpha$ GalCer treatment: vehicle $0.6 \% \pm 0.3$ versus $\alpha$ GalCer $52.1 \% \pm 6.6 ; n=4$ mice/group; $P \leq 0.00004$ ); however, the identification of hepatic iNKT cells at this time point after $\alpha$ GalCer treatment was made more difficult by the well described down-regulation of the cell surface markers on iNKT cells (which are required for their identification by flow cytometry) after cell activation. ${ }^{43}$

In contrast to our observations for iNKT cells, at the 2 and 16 hour time points after $\alpha$ GalCer treatment, only a small increase in IL-17-producing non-NKT cell CD4 ${ }^{+} \mathrm{T}$ cells (ie, classical Th17 cells) could be identified within the liver, suggesting that iNKT cells are the main cellular source of IL-17 within the liver after $\alpha \mathrm{GalCer}$ treatment (\% $\mathrm{CD} 4^{+} \mathrm{NK} 1.1^{-} \mathrm{IL}-17^{+} \mathrm{T}$ cells at 2 hours after vehicle or $\alpha \mathrm{GalCer}$ treatment: vehicle $4.8 \% \pm 0.7$ versus $\alpha \mathrm{GalCer}$ $7.4 \% \pm 1.1 ; n=5$ and 4 mice per group; $P \leq 0.003$; and $\% \mathrm{CD}^{+} \mathrm{NK} 1.1^{-} \mathrm{IL}-17^{+} \mathrm{T}$ cells at 16 hours after vehicle or $\alpha$ GalCer treatment: vehicle $1.3 \% \pm 0.1$ versus $\alpha$ GalCer $4.4 \% \pm 1.6 ; n=5$ mice per group; $P \leq 0.003$ ). These data suggest that the innate production of IL-17 by iNKT cells represents the major hepatic source of IL-17 in this model of acute hepatitis.

\section{Neutralization of IL-17 Exacerbates $\alpha$ GalCer-Induced Hepatitis}

Although IL-17 has mainly been designated as a proinflammatory cytokine, it has more recently been shown to also possess anti-inflammatory properties in some animal models of inflammation. ${ }^{7-11}$ To determine the role of IL-17 in iNKT cell-driven hepatic inflammation, we administered a commercially available IL-17 neutralizing monoclonal antibody ${ }^{10,28}$ before $\alpha$ GalCer administration. IL-17 neutralization before $\alpha \mathrm{GalCer}$ treatment resulted in a significant worsening of $\alpha \mathrm{GalCer}$-induced hepatitis as reflected by a marked increase in plasma ALT levels in anti-IL-17-treated mice, compared to IgG isotype controltreated mice (Figure 5A). The increase in plasma ALT levels in the anti-IL-17 pretreated $\alpha$ GalCer-treated mice was paralleled by a worsening of hepatic histological damage (Figure 5B). In addition, more detailed examination of the lobular inflammatory infiltrate in anti-IL-17pretreated mice, sacrificed 16 hours after $\alpha$ GalCer treatment, showed that the cellular infiltrate was composed mainly of both neutrophils (Figure 5C; Leder stain) and monocytes (Figure 5D; Ly-6C stain). Moreover, we replicated the findings of a worsening of $\alpha \mathrm{GalCer}$-induced hepatitis with IL-17 neutralization using a second IL-17 
neutralizing mAb obtained from a different commercial source (BioLegend, Cedarlane Laboratories Ltd, Burlington, ON, Canada) and targeted to a different epitope of IL-17; which has also been used in other published studies for neutralizing IL-17 bioactivity in vivo ${ }^{44}$ (plasma ALT level at 16 hours after $\alpha \mathrm{GalCer}$ treatment: IgG-treated controls $957 \pm 282 \mathrm{U} / \mathrm{L}$ versus BioLegend anti-IL-17treated $1602 \pm 317 \mathrm{U} / \mathrm{L} ; n=3$ mice/group; $P \leq 0.04$ ).

In a previous study, TNF $\alpha$ produced by hepatic NKT cells was shown to be a critical mediator of $\alpha \mathrm{GalCer}$ induced hepatitis. ${ }^{27}$ Therefore, we determined whether IL-17 neutralization altered the numbers of hepatic TNF $\alpha$ producing iNKT cells after $\alpha$ GalCer treatment. IL-17 neutralization did not alter the number of TNF $\alpha$-producing hepatic iNKT cells at 2 hours after $\alpha$ GalCer treatment (number $\left(\times 10^{3}\right)$ of $\mathrm{TNF} \alpha^{+} \mathrm{CD}^{+}$iNKT cells: IgG-treated $29.7 \pm 11.6$ cells/liver versus anti-IL17-treated $28.2 \pm$ 16.6 cells/liver; $n=4 /$ group; NS), suggesting that IL-17 neutralization did not enhance $\alpha$ GalCer-induced hepatitis by increasing the numbers of hepatic TNF $\alpha$-producing iNKT cells. In addition to TNF $\alpha$, activated iNKT cells also readily produce other cytokines, including IFN $\gamma$ and IL-4, and both of these cytokines have been implicated in the modulation of hepatic inflammatory responses. ${ }^{15,17,18,27}$ Therefore, we also determined whether IL-17 neutralization before $\alpha \mathrm{GalCer}$ administration resulted in alterations in hepatic numbers of IL-4- and/or IFN $\gamma$-producing iNKT cells. Similar to our TNF $\alpha$ results, the numbers of IL-4producing hepatic iNKT cells at 2 hours after $\alpha$ GalCer administration were similar in IgG and anti-IL-17-treated mice (number $\times 10^{3}$ of $\mathrm{IL}_{-} 4^{+} \mathrm{CD}^{+}{ }^{+}$iNKT cells: IgGtreated $4.1 \pm 0.3 \mathrm{cells} /$ liver versus anti-IL-17-treated $3.9 \pm 0.4$ cells/liver; $n=3$ mice/group; NS). In contrast, IL-17 neutralization before $\alpha$ GalCer administration resulted in a significant decrease in the numbers of IFN $\gamma$ producing hepatic iNKT cells 2 hours post- $\alpha$ GalCer (number $\times 10^{3}$ of $\mathrm{IFN} \gamma^{+} \mathrm{CD}^{+}$iNKT cells: IgG-treated $31.1 \pm 1.8$ cells/liver versus anti-IL-17-treated $9.0 \pm 3.9$ cells/liver; $n=3$ mice/group; $P \leq 0.0009$ ).

\section{Exacerbation of $\alpha \mathrm{GalCer-Induced} \mathrm{Hepatitis} \mathrm{after}$ IL-17 Neutralization Is Associated with Increased Hepatic Neutrophil and Monocyte Infiltration}

Both neutrophils and monocytes are recruited into the liver during $\alpha$ GalCer-induced hepatitis. ${ }^{30}$ We have confirmed this observation using flow cytometry of isolated hepatic cells $\left(\mathrm{F} 4 / 80^{+}\right.$monocyte/macrophage count $\times 10^{3}$, vehicle: $42.4 \pm 19.4$ cells/liver versus $\alpha \mathrm{GalCer}$ $225.8 \pm 72.7$ cells/liver, $P<0.0006$; $\mathrm{Gr}^{+}{ }^{+}$neutrophil count $\times 10^{3}$ vehicle: $37.2 \pm 8.9$ cells/liver versus $\alpha \mathrm{Gal}-$ Cer: $71.2 \pm 10.2$ cells/liver, $P<0.001 ; n=4$ and 5 mice/group). Given the well known potential proinflammatory properties of these two cell types, we determined whether IL-17 neutralization in $\alpha$ GalCer-treated mice was associated with an enhancement in the hepatic recruitment of neutrophils and/or monocytes. IL-17 neutralization, before $\alpha$-GalCer administration, resulted in a signif-
A

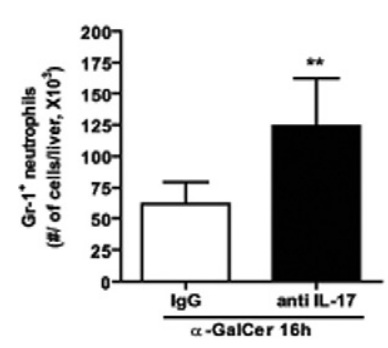

C

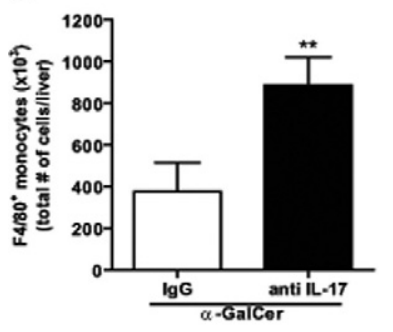

E

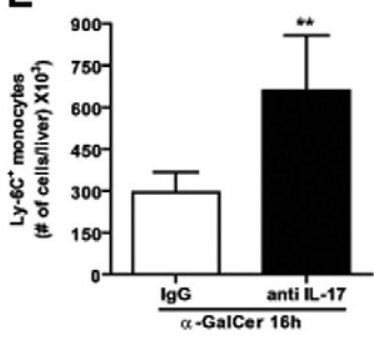

B

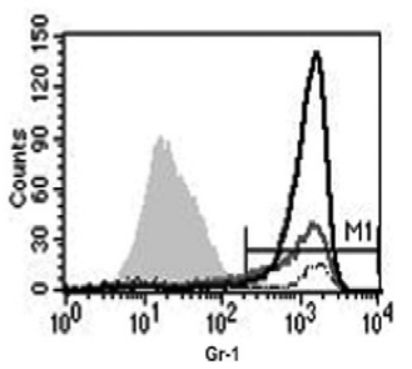

D

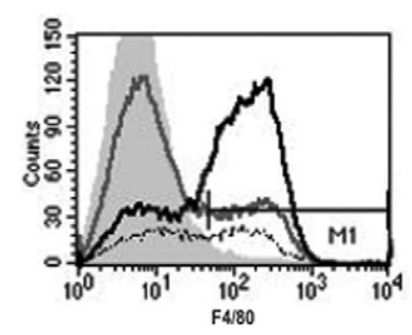

$F$

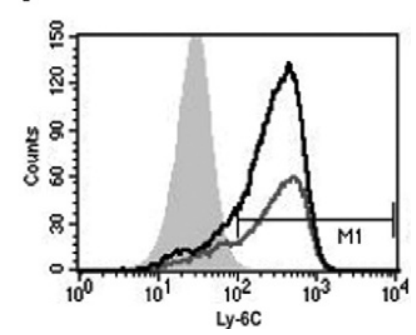

Figure 6. IL-17 neutralization increases the hepatic recruitment of neutrophils and monocytes after $\alpha \mathrm{GalCer}$ administration. Hepatic leukocytes were isolated from anti-IL-17 or IgG isotype pretreated mice which were sacrificed 16 hours after $\alpha$ GalCer treatment. A: Total number of $\mathrm{Gr}-1^{+}\left(\mathrm{Ly}_{-}-6 \mathrm{G}^{+}\right)$ neutrophils per liver. B: Representative histogram plot for $\mathrm{Gr}-1^{+}$hepatic neutrophils. C: Total number of $\mathrm{F} 4 / 80^{+}$monocytes per liver. D: Representative histogram plot for $\mathrm{F} 4 / 80^{+}$hepatic monocytes. E: Total number of Ly- $6 \mathrm{C}^{+}$monocytes per liver. F: Representative histogram plot for Ly-6C ${ }^{+}$ hepatic monocytes. In each histogram plot, the shaded histograms represent the isotype control, the dotted line the non-treated, the gray line the IgG group, and the black line the anti-IL-17-treated group; bars represent the mean $\pm \mathrm{SD}$ of data from four or five mice/group; ${ }^{* *} P<0.005$. Experiments were repeated more than three times with similar results.

icant increase in the hepatic recruitment of both neutrophils and monocytes (Figure 6, A-D) at 16 hours after $\alpha \mathrm{GalCer}$ treatment. Our flow cytometry results, obtained using anti-F4/80 staining for monocytes/macrophages, were confirmed by alternative staining of recruited monocytes with anti-Ly-6C mAb (ie, Kupffer cells are Ly-6C negative ${ }^{32}$; Figure 6, E and F). In contrast, there was no significant difference in the hepatic recruitment of natural killer cells, or $\mathrm{CD} 4^{+} \mathrm{T}$ cells, between IgG and anti-IL-17-treated groups at 16 hours after $\alpha$ GalCer treatment (data not shown).

\section{Monocytes Infiltrating the Liver in $\alpha$ GalCer-Induced Hepatitis after IL-17 Neutralization Have a Proinflammatory Phenotype}

The existence of a heterogeneous monocyte/macrophage population is now well accepted. Inflammatory, or 
A

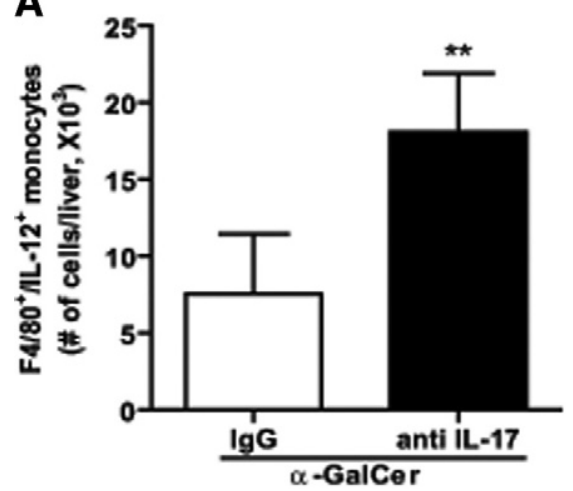

B

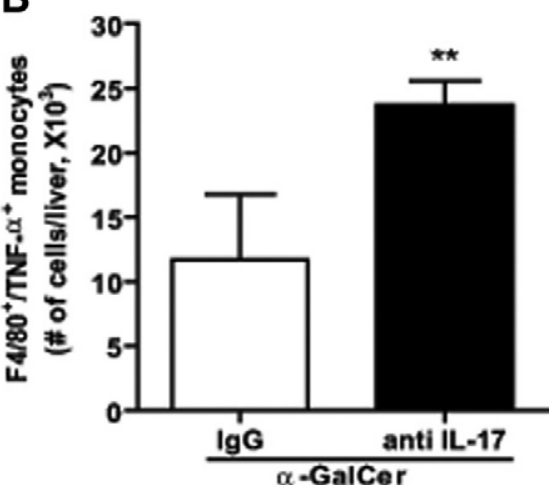

Figure 7. Increased hepatic recruitment of IL-12 and TNF $\alpha$-producing monocytes in $\alpha$ GalCertreated mice after IL-17 neutralization. A: Tota number of $\mathrm{IL}^{-12^{+}}$monocytes per liver. B: Total number of $\mathrm{TNF}^{+}$monocytes per liver, in IgG isotype versus anti-IL-17A-pretreated mice, 16 hours after $\alpha \mathrm{GalCer}$ treatment. Bars represent the mean $\pm \mathrm{SD}$ of data from four to six mice/ group; ${ }^{* *} P<0.005$. Experiments were repeated twice with similar results.
M1 monocytes, predominantly produce IL-12 (but also $\mathrm{TNF} \alpha$ ) and express the surface marker Ly-6C and the chemokine receptor CCR2. ${ }^{32,45,46}$ Therefore, to determine whether the worsening of $\alpha$ GalCer-induced hepatitis after IL-17 neutralization was associated with an increase in the hepatic infiltration of monocytes with an inflammatory or M1 phenotype, we assessed numbers of hepatic monocytes producing IL-12 and TNF $\alpha$ using intracellular flow cytometry. $\mathrm{IL}-17$ neutralization resulted in a significant increase in the numbers of hepatic IL-12and TNF $\alpha$-producing monocytes isolated from $\alpha \mathrm{GalCer}$ treated mice, compared to IgG pretreated $\alpha$ GalCertreated controls, at 16 hours after treatment (Figure 7, A and $\mathrm{B}$ ). In addition, IL-17 neutralization was also associated with an increase in hepatic recruitment of Ly-6C expressing monocytes 16 hours after $\alpha$ GalCer treatment compared to IgG-pretreated control mice (Figure 6, E and $F$ ) as well as an increased number of CCR2 expressing $\mathrm{F} 4 / 80^{+}$monocytes/macrophages (number $\times 10^{3}$ of F4/80 ${ }^{+} \mathrm{CCR}^{+}{ }^{+}$cells: IgG-treated $127.8 \pm 35.3$ cells/liver versus anti-IL-17-treated $196.7 \pm 29.9$ cells/liver; $n=4$ and 3 mice/group; $P \leq 0.04) .{ }^{32}$ In contrast, similar numbers of IL-10-producing (ie, an "M2 phenotype" marker) ${ }^{32,45} \mathrm{~F} 4 / 80^{+}$hepatic monocytes/macrophages were detected by flow cytometry in either IgG or anti-IL-17 pretreated mice 16 hours after $\alpha$ GalCer treatment (number $\times 10^{3}$ of $\mathrm{F} 4 / 80^{+} \mathrm{IL}-10^{+}$cells: IgG-treated $5.2 \pm 2.4$ cells/liver versus anti-IL-17-treated $6.1 \pm 4.9$ cells/liver; $n=5$ mice/group; NS).

It is possible that IL-17 neutralization, in the context of $\alpha$ GalCer-induced hepatitis, may lead to increased immune cell numbers at least in part by enhancing immune cell survival within the liver. To address this possibility, we determined annexin $\mathrm{V}$ staining (a marker of cells undergoing apoptosis) for monocytes/macrophages isolated from the livers of $\alpha$ GalCer-treated mice (16 hours after injection) which had been pretreated with either IgG or anti-IL-17. We found similar annexin $\mathrm{V}$ staining for liver derived monocytes/macrophages in both of these treatment groups (number $\times 10^{3}$ of $\mathrm{F} 4 / 80^{+}$annexin $\mathrm{V}^{+}$cells: IgG-treated $14.2 \pm 8.2$ cells/liver versus anti-IL-17treated $16.3 \pm 7.2$ cells/liver; $n=5$ mice/group; NS), suggesting that IL-17 does not alter monocyte/macrophage survival in this model of hepatitis.

Additionally, it is possible that IL-17 may directly act on monocytes/macrophages within the liver during $\alpha \mathrm{GalCer}$ hepatitis to modulate cytokine production; as has been previously documented for macrophages in the context of sepsis. ${ }^{41}$ Therefore, we used murine bone marrowderived macrophages and activated them in vitro with a combination of IFN $\gamma$ and endotoxin (lipopolysaccharide) to determine the effect of exogenous rmIL-17 on macrophage IL-12 production, as determined by flow cytometry. We found no evidence of an IL-17-mediated effect on macrophage IL-12 production in this in vitro experimental paradigm, using concentrations of rmlL-17 (ie, $100 \mathrm{pg} / \mathrm{ml}$ ) previously shown to be biologically active for macrophages cultured in vitro ${ }^{41}$ (\% of $\mathrm{IL}_{-1} 2^{+}$macrophages: IFN $\gamma+$ lipopolysaccharide $10.8 \pm 1.0 \%$ versus IFN $\gamma+$ lipopolysaccharide + rmIL-17 $10.2 \pm 1.8 \% ; n=$ 5 and 4 wells/group; NS).

\section{IL-17 Neutralization Induces Increased Relevant Monocyte and Neutrophil Chemoattractant Chemokine mRNA and Protein Expression Within the Liver after $\alpha$ GalCer Administration}

CXC chemokines, in particular CXCL1/KC, CXCL2/MIP-2, and CXCL5/LIX, are important chemoattractants of neutrophils to inflammatory sites. ${ }^{34}$ In addition, the CC chemokine CCL2/MCP-1 is an important monocyte chemoattractant to sites of tissue injury. ${ }^{34}$ Increased tissue expression of these chemokines is associated with a worsening of various inflammatory conditions. ${ }^{35,36,47,48}$ Considering the important role chemokines play in the pathogenesis of hepatic inflammation, we assessed the hepatic mRNA expression of CXCL1/KC, CXCL2/MIP-2, CXCL5/LIX, and CCL2/MCP-1. IL-17 neutralization before $\alpha$ GalCer administration resulted in a significant increase in the hepatic mRNA expression of CXCL5/LIX compared to $\alpha$ GalCer-treated, IgG isotype pretreated mice at 2 hours after $\alpha \mathrm{GalCer}$ administration (Figure 8A). Similarly, $\mathrm{IL}-17$ neutralization resulted in a significant increase in the hepatic mRNA expression of CCL2/MCP-1 compared to $\alpha$ GalCer-treated, IgG-pretreated mice (Figure $8 \mathrm{~B}$ ). In contrast, no difference was observed in the hepatic mRNA expression of the two neutrophil chemoattractant chemokines, CXCL1/KC or CXCL2/MIP-2, between the IgG or anti-IL-17 pretreated groups which received $\alpha$ GalCer (fold change in hepatic CXCL1/KC mRNA ex- 
A

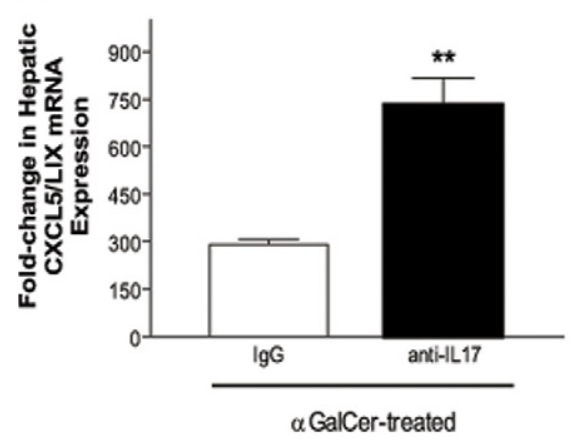

C

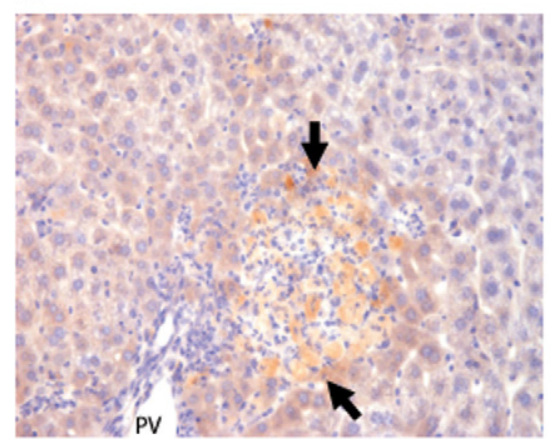

B

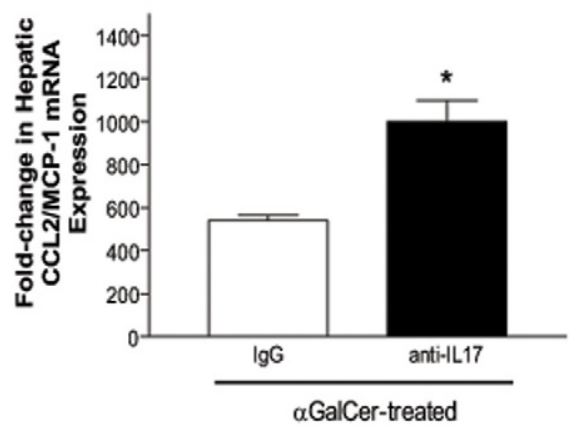

D

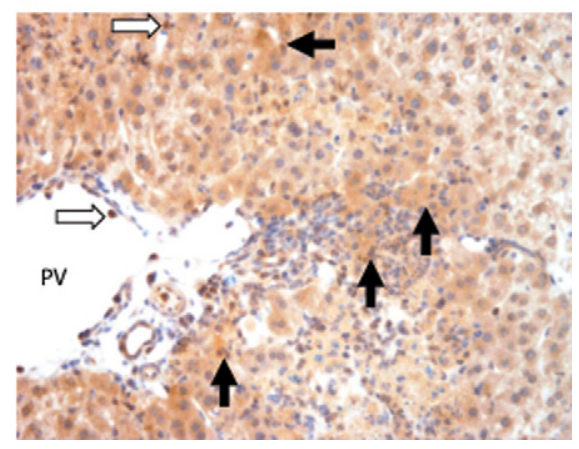

Figure 8. IL-17 neutralization results in increased hepatic expression of the chemokines CXCL5/LIX and CCL2/MCP-1 in $\alpha$ GalCer-induced hepatitis. Relative fold-increase in hepatic mRNA expression (relative to hepatic levels in vehicle-treated mice) of CXCL5/LIX (neutrophil chemoattractant) (A) and CCL2/MCP-1 (monocyte chemoattractant) (B) in anti-IL-17 versus IgG isotype pretreated mice which were sacrificed 2 hours after $\alpha$ GalCer treatment. Bars represent the mean $\pm \mathrm{SD}$ of four mice/group; ${ }^{* * *} P<$ 0.002 and ${ }^{*} P \leq 0.01$ versus respective IgG-pretreated groups. Experiments were repeated twice with similar results. Hepatic CXCL5 and CCL2 protein expression (brown stained cells) was determined by immunohistochemistry in anti-IL-17-pretreated mice which were sacrificed 16 hours after $\alpha$ GalCer administration. C: Hepatic CXCL5 expression is essentially confined to hepatocytes in and around areas of lobular hepatitis (black arrows). D: In contrast, CCL2 expression was more widespread and was evident in hepatocytes (black arrows) as well as immune cells within blood vessels and the hepatic parenchyma (white arrows). Similar observations were made in liver sections from three mice/group. Vehicle-treated control mice demonstrated no detectable staining for CXCL5 or CCL2. PV, portal vein. pression: IgG $126.0 \pm 54.1$ versus anti-IL-17 $112.7 \pm$ $45.1 ; n=4$ mice/group; NS; fold change in hepatic CXCL2/MIP-2 mRNA expression: IgG $3115.0 \pm 1881.4$ versus anti-IL-17 997.6 \pm 246.9; $n=4$ mice/group; NS).

To complement our hepatic CCL2 and CXCL5 mRNA findings, we performed immunohistochemistry on liver sections obtained from mice pretreated with anti-IL-17 and sacrificed 16 hours after $\alpha$ GalCer administration, to determine the cellular sources of both CXCL5 and CCL2 production. We found that hepatic CXCL5 expression 16 hours post- $\alpha$ GalCer was relatively restricted to hepatocytes in areas surrounding lobular inflammation (Figure 8C). In contrast, CCL2 expression was readily evident and was noted in hepatocytes surrounding inflamed portal areas, as well as in areas adjacent to lobular hepatitis. In addition, CCL2 appeared to also be strongly expressed in immune cells (morphologically resembling monocytes/macrophages) present within the lumen of blood vessels (ie, portal vein) as well as in sinusoids and the hepatic parenchyma (Figure 8D).

\section{rm/L-17 Treatment Suppresses $\alpha$ GalCer-Induced Hepatitis in Association with Decreased Recruitment of Inflammatory Monocytes into the Liver}

To support our findings of an anti-inflammatory role for IL-17 in $\alpha$ GalCer-induced hepatitis, we determined the effect of exogenously administered rmIL-17 on the severity of hepatitis 16 hours after $\alpha$ GalCer administration. rmIL-17 treatment resulted in a significant decrease in $\alpha$ GalCer-induced hepatitis as reflected by a reduction in plasma ALT levels (Figure 9A). Moreover, rmIL-17 admin- istration resulted in a significant reduction in total numbers of hepatic $\mathrm{F} 4 / 80^{+}$monocytes/macrophages at 16 hours after $\alpha$ GalCer treatment, compared to PBStreated mice which received $\alpha$ GalCer (Figure 9B). In addition, rmIL-17 treatment significantly reduced the hepatic numbers of IL-12- and TNF $\alpha$-producing F $4 / 80^{+}$ monocytes/macrophages in $\alpha$ GalCer-treated mice, compared to PBS-treated mice that received $\alpha$ GalCer (Figure 9, C and D).

\section{Discussion}

NKT cells are an important component of the innate immune response, which is of critical importance early during the development of the hepatic inflammatory response. ${ }^{16}$ Administration of the glycolipid $\alpha$ GalCer specifically activates NKT cells within the liver, resulting in their rapid production of numerous cytokines, including IFN $\gamma$ and $\operatorname{TNF} \alpha$, which are important regulators of the hepatic immune response. ${ }^{15-17,27}$ Moreover, TNF $\alpha$ produced by NKT cells activated by $\alpha$ GalCer in vivo has been shown to be a central mediator of hepatitis which develops in mice in response to $\alpha$ GalCer administration. ${ }^{27}$ NKT cells have also recently been shown to be capable of rapidly producing the cytokine $\mathrm{IL}-17$ after activation. ${ }^{19-21,23} \mathrm{IL}-17$ has been implicated as a proinflammatory, but more recently also as an anti-inflammatory regulator in models of inflammation, although the role of $\mathrm{IL}-17$ in hepatic inflammation remains controversial. ${ }^{13,14,49}$ Our current findings demonstrate that after $\alpha$ GalCer administration, hepatic iNKT cells rapidly produce IL-17 in the absence of significant production of IL-17 by classical Th17 cells within the liver. Moreover, 
A

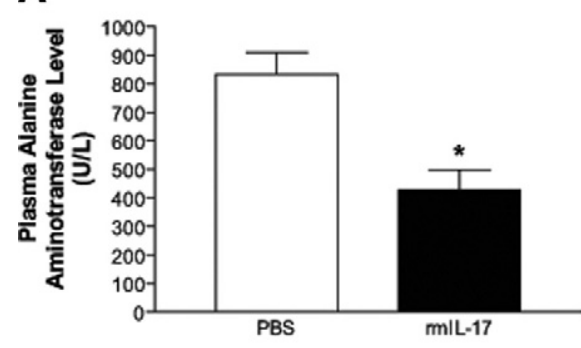

C

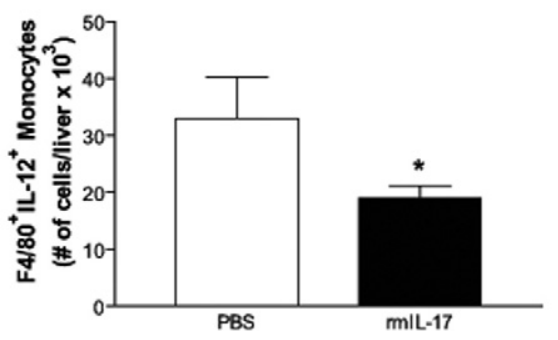

B

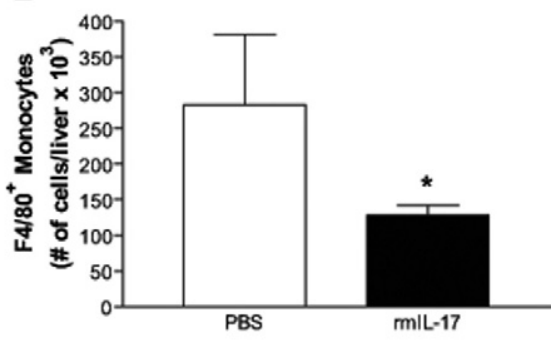

D

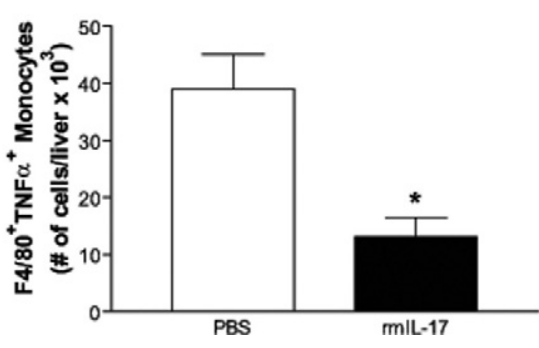

Figure 9. Exogenous rmIL-17 administration ameliorates hepatitis as measured 16 hours after $\alpha$ GalCer administration. A: rmIL-17 treatment resulted in a significant decrease in $\alpha$ GalCer-induced hepatitis as reflected by a reduction in plasma alanine aminotransferase levels $\left({ }^{*} P \leq\right.$ 0.002). Moreover, in B rmIL-17 administration resulted in significant decreases in the total number of hepatic $\mathrm{F} 4 / 80^{+}$monocytes/macrophages per liver $\left({ }^{*} P \leq 0.02\right)$. C: The total number of $\mathrm{F} 4 / 80^{+} \mathrm{IL}-12^{+}$monocytes/macrophages per liver $\left.{ }^{*} P \leq 0.02\right)$. D: the total number of F4/ $80^{+} \mathrm{TNF} \alpha^{+}$monocytes/macrophages per liver $\left({ }^{*} P \leq 0.01\right)$ compared to PBS-treated controls that received $\alpha$ GalCer. Bars represent the mean $\pm \mathrm{SD}$ of $n=4 \mathrm{mice} /$ group. the rapid production of IL-17 within the liver after $\alpha \mathrm{GalCer}$ administration preceded the development of overt biochemical or histological hepatitis in these mice. Neutralization of IL-17 resulted in a significant augmentation of $\alpha$ GalCer-induced hepatitis which was accompanied by the increased recruitment of innate immune cells into the liver; including significant numbers of neutrophils and monocytes. Moreover, enhanced hepatitis in anti-IL-17 $\alpha$ GalCer-treated mice was characterized histologically by an extension of the inflammatory infiltrate, containing predominantly monocytes and neutrophils, out of the portal areas and into the hepatic lobule; the clinical hallmark of more severe hepatitis in patients with inflammatory liver disease. In contrast, exogenous rmIL-17 administration suppressed $\alpha$ GalCer-induced hepatitis and associated cellular infiltration. Therefore, our findings are consistent with $\mathrm{IL}-17$ released within the liver early after NKT cell activation, and as a part of the innate immune response, playing a novel anti-inflammatory role within the liver during the development of subsequent hepatic inflammation; in part by inhibiting the infiltration of monocytes and neutrophils into the liver parenchyma.

NKT cells are enriched within the liver, constituting up to $30 \%$ of hepatic lymphocytes in the mouse. ${ }^{15,16}$ The majority of hepatic NKT cells in the mouse express the surface markers NK1.1 (in C57BL/6 mice) and CD4, and are classified as invariant NKT cells. ${ }^{16}$ NKT cells are capable of rapidly producing IL-17 on activation; however, studies to date have suggested that NK1.1 expressing NKT cells do not produce IL-17. ${ }^{19,21-23}$ We currently demonstrate that within the liver, after treatment with $\alpha$ GalCer, NK1.1 and CD4 expressing NKT cells readily produce IL-17 in the absence of significant production of IL-17 by other cell types (ie, classical Th17 cells) within the liver. Our findings of this very rapid activation of NKT cells in the liver to produce IL-17 after $\alpha$ GalCer treatment allowed us to determine the potential role played by the early innate release of IL-17 in the subsequent development of hepatitis.
IL-17 was originally identified as a proinflammatory mediator, mainly in models of autoimmune and adaptive immunity ${ }^{1,4-6}$; however, more recently it has become clear that IL-17 can also suppress the inflammatory response. ${ }^{7-11}$ Within the liver the role of $\mathrm{IL}-17$ in regulating inflammation remains controversial. In ischemia-reperfusion injury of the liver, which is characterized by a rapid hepatic accumulation of CD4 positive T cells, NKT cells and neutrophils, IL-17 neutralization did not alter the development of subsequent hepatitis as indicated by plasma ALT levels ${ }^{50}$; however, the specific cellular source of IL-17 production within the liver was not identified in this study. Similarly, in the concanavalin A model of $\mathrm{T}$ cell mediated hepatitis, Zenewicz et $\mathrm{al}^{13}$ found that $\mathrm{IL}-17$ had no role in modulating the inflammatory response. In contrast, using the same model of $\mathrm{T}$ cellmediated hepatitis, Nagata et $\mathrm{al}^{14}$ demonstrated that IL-17 was proinflammatory. The reason for the discrepant results in these two studies is unclear. In our studies, using the $\alpha$ GalCer-induced hepatitis model, we found that IL-17 neutralization worsened hepatitis. These findings suggest that IL-17 may regulate hepatitis in different ways depending on the type of inflammatory response which characterizes a given model. The concanavalin A model of hepatitis is characterized by a profound generalized immune system activation and the development of severe acute hepatitis associated with a significant adaptive immune response and the infiltration of CD4 positive cells into the liver ${ }^{51}$; many of the infiltrating CD4 positive T cells also likely produce IL-17. In contrast, $\alpha$ GalCerinduced hepatitis is of mild to moderate intensity and is associated mainly with an innate immune response, and not by a significant accumulation of CD4 positive cells within the liver ${ }^{30}$ (Wondimu and Swain, unpublished observations). Previous studies demonstrating an anti-inflammatory role for IL-17 in tissues outside the liver have in general made this observation in models characterized by a more prominent innate immune response. ${ }^{8-11}$ Therefore, taken together with ours, these findings sup- 
port an interesting possibility that the ultimate biological effects of IL-17 during an inflammatory response may depend on the context of the inflammatory milieu into which it is released, and whether inflammation is characterized more prominently by an innate or adaptive immune response.

$\alpha$ GalCer-induced hepatitis has previously been shown to critically depend on TNF $\alpha$ produced by NKT cells in the liver. ${ }^{27}$ Indeed, in our current study we have confirmed that NKT cells rapidly produce TNF $\alpha$ in this model, although neutralization of IL-17 did not alter the number of TNF $\alpha$-producing NKT cells within the liver after $\alpha$ GalCer administration. Hepatic iNKT cells also rapidly produce IL-4 and IFN $\gamma$ after activation. ${ }^{15-18}$ Similar to TNF $\alpha$, the number of hepatic iNKT cells producing IL-4 was not different in $\alpha$ GalCer-treated mice pretreated with IgG or anti-IL-17. However, IL-17 neutralization resulted in a greater than threefold lower number of hepatic IFN $\gamma$-producing iNKT cells compared to IgG pretreated $\alpha$ GalCer-treated mice. This observation is interesting and potentially relevant to our observed worsening of $\alpha \mathrm{GalCer}$-induced hepatitis by IL-17 neutralization, as IFN $\gamma$ has been previously shown to have a hepatoprotective effect in this model of hepatitis via an unknown mechanism. ${ }^{27}$

IL-17 neutralization enhanced the hepatic recruitment of neutrophils and monocytes after $\alpha \mathrm{GalCer}$ treatment. Furthermore, neutralization of IL-17 augmented $\alpha$ GalCerinduced increases in the mRNA expression of the neutrophil chemoattractant CXCXL5/LIX and the monocyte chemoattractant CCL2/MCP-1 within the liver. In contrast, hepatic mRNA expression of two other important neutrophil chemokines were unchanged in the liver after IL-17 neutralization; specifically CXCXL1/MIP-2 and CXCXL2/ $\mathrm{KC}$. These findings suggest that IL-17 may differentially regulate the expression of chemokines within the liver which play an important role in orchestrating the ultimate characteristics of the innate inflammatory response. The pattern of hepatic expression of CXCL5 and CCL2 in $\alpha$ GalCer-treated mice after IL-17 neutralization is also of interest, in that the expression of both of these chemokines was most prominent in hepatocytes and appeared to be directly related to the lobular extension of the associated inflammatory infiltrate. These observations further support an important role for these chemokines in the pathogenesis of hepatic inflammation in this model. In contrast to CXCL5, CCL2 was also prominently expressed in immune cells within the liver (with morphology suggestive of monocytes) in $\alpha$ GalCer-treated mice, suggesting that recruited immune cells which produce CCL2/MCP-1 may induce the further recruitment of additional cells into the liver which express CCR2 (eg, M1 monocytes), the receptor for CCL2/MCP-1.

The relative importance of monocytes and neutrophils in driving liver inflammation in the $\alpha$ GalCer-induced model of hepatitis is unknown. Clearly, significant hepatic recruitment of both of these cell types occurs in the context of $\alpha \mathrm{GalCer}$-induced hepatitis (our current data and previous reports), ${ }^{30,52}$ and we show that a significant number of monocytes/macrophages within the liver after $\alpha$ GalCer treatment produce the proinflammatory cytokines TNF $\alpha$ and IL-12. However, macrophage depletion studies have previously suggested a possible paradoxical hepatoprotective role of resident hepatic macrophages in $\alpha$ GalCer-induced hepatitis, ${ }^{27}$ although this finding was not confirmed in another study which suggested a limited role for hepatic macrophages in this model. ${ }^{53}$ These observations suggest that resident hepatic macrophages (ie, Kupffer cells) in $\alpha$ GalCer-treated mice may fulfill a complex role in modulating the inflammatory response, the ultimate outcome of which may relate to a balance between cytokines and other mediators produced by Kupffer cells, and those produced by monocytes which are recruited to the liver in response to $\alpha \mathrm{GalCer}$ treatment. Importantly, we show that numbers of hepatic macrophages/monocytes producing $\mathrm{IL}-12$ and TNF $\alpha$ after $\alpha$ GalCer-treatment are augmented by IL-17 neutralization, whereas the numbers of IL-10-producing hepatic macrophages/monocytes remained unchanged; findings consistent with a role for IL-17 in the regulation of hepatic levels of proinflammatory cytokines which likely contribute to the pathogenesis of $\alpha \mathrm{GalCer}$-induced hepatitis. Neutrophil recruitment to the liver is also enhanced by $\alpha$ GalCer treatment, and neutrophils have been shown to significantly regulate the development of liver inflammation in other models of NKT cell-driven hepatitis (eg, that mediated by concanavalin A). ${ }^{31}$ Therefore, similar to observations made in the concanavalin A-induced model of hepatitis, neutrophils likely constitute a significant mediator of $\alpha$ GalCer-induced hepatitis; an effect enhanced by IL-17 neutralization. Based on these observations, the relative roles played by neutrophils and monocytes/macrophages in the development of $\alpha \mathrm{GalCer-induced} \mathrm{hepa-}$ titis warrants further investigation.

In summary, we have demonstrated that hepatic $\mathrm{CD} 4^{+}$ and NK $1.1^{+}$NKT cells are rapidly activated by $\alpha \mathrm{GalCer}$ to produce IL-17. Moreover, IL-17 produced in the context of $\alpha$ GalCer-induced hepatitis plays a novel anti-inflammatory role by regulating the recruitment of proinflammatory innate immune cells into the liver. Our findings suggest that in the context of activation of the innate immune response and the development of hepatitis, IL-17 can play a beneficial role by attenuating inflammation.

\section{Acknowledgments}

We acknowledge the following individuals from the University of Calgary for their expert assistance: Dr. Pina Colarusso, Carol Gwozd, and Mr. Chris Meijndert (Snyder III Institute, Immunohistochemistry and Live Cell Imaging Core Laboratory); Karen K.H. Poon (Snyder III Institute, Molecular Biology Core Laboratory); Laurie Kennedy and Laurie Robertson (Flow Cytometry Core Laboratory, Faculty of Medicine).

\section{References}

1. Miossec $P$, Korn T, Kuchroo VK: Interleukin-17 and type 17 helper $T$ cells. N Engl J Med 2009, 361:888-898

2. Harrington LE, Hatton RD, Mangan PR, Turner H, Murphy TL, Murphy $\mathrm{KM}$, Weaver CT: Interleukin 17-producing CD4+ effector T cells 
develop via a lineage distinct from the Thelper type 1 and 2 lineages. Nat Immunol 2005, 6:1123-1132

3. Park $\mathrm{H}$, Li Z, Yang XO, Chang $\mathrm{SH}$, Nurieva $R$, Wang $Y H$, Wang $Y$, Hood L, Zhu Z, Tian Q, Dong C: A distinct lineage of CD4 T cells regulates tissue inflammation by producing interleukin 17. Nat Immunol 2005, 6:1133-1141

4. Langrish $\mathrm{CL}$, Chen $\mathrm{Y}$, Blumenschein WM, Mattson J, Basham B, Sedgwick JD, McClanahan T, Kastelein RA, Cua DJ: IL-23 drives a pathogenic $T$ cell population that induces autoimmune inflammation. J Exp Med 2005, 201:233-240

5. Lubberts E, Koenders MI, Oppers-Walgreen B, van den Bersselaar L, Coenen-de Roo CJ, Joosten LA, van den Berg WB: Treatment with a neutralizing anti-murine interleukin-17 antibody after the onset of collagen-induced arthritis reduces joint inflammation, cartilage destruction, and bone erosion. Arthritis Rheum 2004, 50:650-659

6. Komiyama Y, Nakae S, Matsuki T, Nambu A, Ishigame H, Kakuta S, Sudo K, Iwakura Y: IL-17 plays an important role in the development of experimental autoimmune encephalomyelitis. J Immunol 2006 , $177: 566-573$

7. Schnyder-Candrian S, Togbe D, Couillin I, Mercier I, Brombacher F, Quesniaux V, Fossiez F, Ryffel B, Schnyder B: Interleukin-17 is a negative regulator of established allergic asthma. J Exp Med 2006 203:2715-2725

8. Otani $\mathrm{K}$, Watanabe $\mathrm{T}$, Tanigawa $\mathrm{T}$, Okazaki $\mathrm{H}$, Yamagami $\mathrm{H}$, Watanabe K, Tominaga K, Fujiwara Y, Oshitani N, Arakawa T: Antiinflammatory effects of IL-17A on Helicobacter pylori-induced gastritis. Biochem Biophys Res Commun 2009, 382:252-258

9. Ogawa A, Andoh A, Araki Y, Bamba T, Fujiyama Y: Neutralization of interleukin-17 aggravates dextran sulfate sodium-induced colitis in mice. Clin Immunol 2004, 110:55-62

10. O'Connor Jr W, Kamanaka M, Booth CJ, Town T, Nakae S, Iwakura Y, Kolls JK. Flavell RA: A protective function for interleukin 17A in T cell-mediated intestinal inflammation. Nat Immunol 2009, 10:603-609

11. Taleb S, Romain M, Ramkhelawon B, Uyttenhove C, Pasterkamp G Herbin O, Esposito B, Perez N, Yasukawa H, Van Snick J, Yoshimura A, Tedgui A, Mallat Z: Loss of SOCS3 expression in T cells reveals a regulatory role for interleukin-17 in atherosclerosis. J Exp Med 2009 206:2067-2077

12. Lemmers A, Moreno C, Gustot T, Marechal R, Degre D, Demetter $P$, de Nadai P, Geerts A, Quertinmont E, Vercruysse V, Le Moine O, Deviere J: The interleukin-17 pathway is involved in human alcoholic liver disease. Hepatology 2009, 49:646-657

13. Zenewicz LA, Yancopoulos GD, Valenzuela DM, Murphy AJ, Karow M, Flavell RA: Interleukin-22 but not interleukin-17 provides protection to hepatocytes during acute liver inflammation. Immunity 2007 27:647-659

14. Nagata T, McKinley L, Peschon JJ, Alcorn JF, Aujla SJ, Kolls JK Requirement of IL-17RA in Con A induced hepatitis and negative regulation of IL-17 production in mouse T cells. J Immunol 2008 , 181:7473-7479

15. Swain MG: Hepatic NKT cells: friend or foe? Clin Sci (Lond) 2008 114:457-466

16. Bendelac A, Savage PB, Teyton L: The biology of NKT cells. Annu Rev Immunol 2007, 25:297-336

17. Takeda K, Hayakawa Y, Van Kaer L, Matsuda H, Yagita H, Okumura $\mathrm{K}$ : Critical contribution of liver natural killer T cells to a murine model of hepatitis. Proc Natl Acad Sci USA 2000, 97:5498-5503

18. Ajuebor MN, Aspinall Al, Zhou F, Le T, Yang Y, Urbanski SJ, Sidobre S, Kronenberg M, Hogaboam CM, Swain MG: Lack of chemokine receptor CCR5 promotes murine fulminant liver failure by preventing the apoptosis of activated CD1d-restricted NKT cells. J Immuno 2005, 174:8027-8037

19. Michel ML, Keller AC, Paget C, Fujio M, Trottein F, Savage PB, Wong $\mathrm{CH}$, Schneider E, Dy M, Leite-de-Moraes MC: Identification of an IL-17-producing NK1.1(neg) iNKT cell population involved in airway neutrophilia. J Exp Med 2007, 204:995-1001

20. Michel ML, Mendes-da-Cruz D, Keller AC, Lochner M, Schneider E Dy M, Eberl G, Leite-de-Moraes MC: Critical role of ROR-gamma in a new thymic pathway leading to IL-17-producing invariant NKT cell differentiation. Proc Natl Acad Sci USA 2008, 105:19845-19850

21. Yoshiga Y, Goto D, Segawa S, Ohnishi Y, Matsumoto I, Ito S, Tsutsumi A, Taniguchi M, Sumida T: Invariant NKT cells produce IL-17 through IL-23-dependent and -independent pathways with potential modula- tion of Th17 response in collagen-induced arthritis. Int $\mathrm{J}$ Mol Med 2008, 22:369-374

22. Lee KA, Kang MH, Lee YS, Kim YJ, Kim DH, Ko HJ, Kang CY: A distinct subset of natural killer T cells produces IL-17, contributing to airway infiltration of neutrophils but not to airway hyperreactivity. Cell Immunol 2008, 251:50-55

23. Coquet JM, Chakravarti S, Kyparissoudis K, McNab FW, Pitt LA, McKenzie BS, Berzins SP, Smyth MJ, Godfrey DI: Diverse cytokine production by NKT cell subsets and identification of an IL-17-producing CD4-NK1.1- NKT cell population. Proc Natl Acad Sci USA 2008, 105:11287-11292

24. Nakagawa R, Nagafune I, Tazunoki $Y$, Ehara H, Tomura H, lijima R, Motoki K, Kamishohara M, Seki S: Mechanisms of the antimetastatic effect in the liver and of the hepatocyte injury induced by alphagalactosylceramide in mice. J Immunol 2001, 166:6578-6584

25. Ajuebor MN, Wondimu Z, Hogaboam CM, Le T, Proudfoot AE, Swain MG: CCR5 deficiency drives enhanced natural killer cell trafficking to and activation within the liver in murine $T$ cell-mediated hepatitis. Am J Pathol 2007, 170:1975-1988

26. Osman Y, Kawamura T, Naito T, Takeda K, Van Kaer L, Okumura K, Abo T: Activation of hepatic NKT cells and subsequent liver injury following administration of alpha-galactosylceramide. Eur J Immunol 2000, 30:1919-1928

27. Biburger M, Tiegs G: Alpha-galactosylceramide-induced liver injury in mice is mediated by TNF-alpha but independent of Kupffer cells. J Immunol 2005, 175:1540-1550

28. Hofstetter HH, Ibrahim SM, Koczan D, Kruse N, Weishaupt A, Toyka KV, Gold R: Therapeutic efficacy of IL-17 neutralization in murine experimental autoimmune encephalomyelitis. Cell Immunol 2005, 237:123-130

29. Zhang Z, Clarke TB, Weiser JN: Cellular effectors mediating Th17dependent clearance of pneumococcal colonization in mice. J Clin Invest 2009, 119:1899-1909

30. Delarbre C, Gachelin G: Injection of the immuno-modulatory drug alpha-galactosylceramide results in the recruitment of a large population of antigen-presenting cells into the liver of C57BL/6 mice. Microbes Infect 2004, 6:360-368

31. Bonder CS, Ajuebor MN, Zbytnuik LD, Kubes P, Swain MG: Essential role for neutrophil recruitment to the liver in concanavalin A-induced hepatitis. J Immunol 2004, 172:45-53

32. Geissmann F, Jung S, Littman DR: Blood monocytes consist of two principal subsets with distinct migratory properties. Immunity 2003, 19:71-82

33. Whiteland JL, Nicholls SM, Shimeld C, Easty DL, Williams NA, Hill TJ Immunohistochemical detection of T-cell subsets and other leukocytes in paraffin-embedded rat and mouse tissues with monoclonal antibodies. J Histochem Cytochem 1995, 43:313-320

34. Charo IF, Ransohoff RM: The many roles of chemokines and chemokine receptors in inflammation. N Engl J Med 2006, 354:610-621

35. Jaeschke $\mathrm{H}$ : Chemokines and liver inflammation: the battle between pro- and anti-inflammatory mediators. Hepatology 1997, 25:252-253

36. Shields PL, Morland CM, Salmon M, Qin S, Hubscher SG, Adams DH: Chemokine and chemokine receptor interactions provide a mechanism for selective $T$ cell recruitment to specific liver compartments within hepatitis C-infected liver. J Immunol 1999, 163:6236-6243

37. Overbergh L, Giulietti A, Valckx D, Decallonne R, Bouillon R, Mathieu C: The use of real-time reverse transcriptase PCR for the quantification of cytokine gene expression. J Biomol Tech 2003, 14:33-43

38. Van Lint P, Wielockx B, Puimege L, Noel A, Lopez-Otin C, Libert C: Resistance of collagenase-2 (matrix metalloproteinase-8)-deficient mice to TNF-induced lethal hepatitis. J Immunol 2005, 175:76427649

39. Hammerschmidt E, Loeffler I, Wolf G: Morg1 heterozygous mice are protected from acute renal ischemia-reperfusion injury. Am J Physiol Renal Physiol 2009, 297:F1273-F1287

40. Yates RM, Hermetter A, Taylor GA, Russell DG: Macrophage activation downregulates the degradative capacity of the phagosome. Traffic 2007, 8:241-250

41. Flierl MA, Rittirsch D, Gao H, Hoesel LM, Nadeau BA, Day DE, Zetoune FS, Sarma JV, Huber-Lang MS, Ferrara JL, Ward PA: Adverse functions of IL-17A in experimental sepsis. FASEB $J$ 2008, 22:2198-2205

42. Rachitskaya AV, Hansen AM, Horai R, Li Z, Villasmil R, Luger D, Nussenblatt RB, Caspi RR: Cutting edge: nKT cells constitutively 
express IL-23 receptor and RORgammat and rapidly produce IL-17 upon receptor ligation in an IL-6-independent fashion. J Immunol 2008, 180:5167-5171

43. Wilson MT, Johansson C, Olivares-Villagomez D, Singh AK, Stanic AK, Wang CR, Joyce S, Wick MJ, Van Kaer L: The response of natural killer T cells to glycolipid antigens is characterized by surface receptor down-modulation and expansion. Proc Natl Acad Sci USA 2003 100:10913-10918

44. Yen D, Cheung J, Scheerens H, Poulet F, McClanahan T, McKenzie B, Kleinschek MA, Owyang A, Mattson J, Blumenschein W, Murphy E, Sathe M, Cua DJ, Kastelein RA, Rennick D: IL-23 is essential for T cell-mediated colitis and promotes inflammation via IL-17 and IL-6. J Clin Invest 2006, 116:1310-1316

45. Mantovani A, Sica A, Locati M: Macrophage polarization comes of age. Immunity 2005, 23:344-346

46. Mantovani A, Sica A, Sozzani S, Allavena P, Vecchi A, Locati M: The chemokine system in diverse forms of macrophage activation and polarization. Trends Immunol 2004, 25:677-686

47. Ronis MJ, Butura A, Korourian S, Shankar K, Simpson P, Badeaux J, Albano E, Ingelman-Sundberg M, Badger TM: Cytokine and chemokine expression associated with steatohepatitis and hepatocyte pro- liferation in rats fed ethanol via total enteral nutrition. Exp Biol Med (Maywood) 2008, 233:344-355

48. Szabo G, Mandrekar P, Dolganiuc A: Innate immune response and hepatic inflammation. Semin Liver Dis 2007, 27:339-350

49. Miossec P: IL-17 and Th17 cells in human inflammatory diseases. Microbes Infect 2009, 11:625-630

50. Caldwell CC, Okaya T, Martignoni A, Husted T, Schuster R, Lentsch $A B$ : Divergent functions of $C D 4+T$ lymphocytes in acute liver inflammation and injury after ischemia-reperfusion. Am J Physiol Gastrointest Liver Physiol 2005, 289:G969-G976

51. Tiegs G, Hentschel J, Wendel A: A T cell-dependent experimental liver injury in mice inducible by concanavalin A. J Clin Invest 1992, 90:196-203

52. Kakimi K, Guidotti LG, Koezuka Y, Chisari FV: Natural killer T cell activation inhibits hepatitis B virus replication in vivo. J Exp Med 2000, 192:921-930

53. Nakashima H, Kinoshita M, Nakashima M, Habu Y, Shono S, Uchida T, Shinomiya N, Seki S: Superoxide produced by Kupffer cells is an essential effector in concanavalin A-induced hepatitis in mice. Hepatology 2008, 48:1979-1988 